but not rare, ${ }^{37}$ diagnosis of a biparietal thinning could be confirmed in the CT scans. While this pathology of the skull is not mentioned in the description of 1824 , a hole in the right parietal bone was discovered at this time and interpreted as a means of brain removal. This (most likely intentional) perforation carried out during the mummification procedure is an atypical observation. Perforation of the skull - additional to a trans-nasal excerebration is found in only a few cases. Furthermore, several teeth were lost post-mortem, as stated in the 1824 record. As could be seen in the CT scans, some of these were displaced in the pharynx and larynx and others in the rear of the cranial cavity - also a rare finding. The teeth in the cranium were possibly placed there through the hole in the parietal thinning. The documentation of the unwrapping of the mummy in the early nineteenth century and the modern re-assessments complement each other in the description of this most interesting case and shed new light into funeral practices in Ancient Egyptian times.

Roger SEILER AND Frank RüHLI

\title{
New Kingdom activities in the Kharga Oasis: The scribe Userhat travels westwards
}

Notes on a New Kingdom graffito of a scribe, found along the Darb Ain Amur, an area between Kharga and Dakhla Oases.

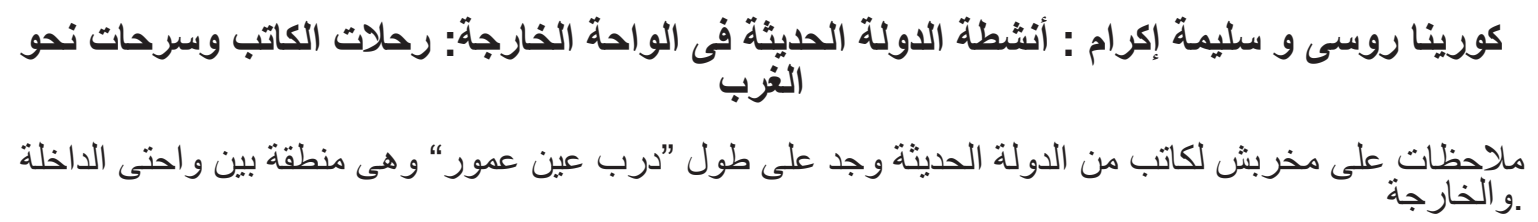

The North Kharga Oasis Survey (NKOS) has been systematically exploring the northern portion of the Kharga Oasis since 200I. ${ }^{\mathrm{I}} \mathrm{NKOS}$ carried out surveys of the major late-Roman sites located in the main depression, ${ }^{2}$ and thereafter started the on-going exploration of the Darb Ain Amur, the ancient caravan route that links Kharga and Dakhla Oases via the spring of Ain Amur $^{3}$ (fig. I). Along the various branches of this route, NKOS located and studied

37 H. Isherwood, H. Jarvis, and R. A. Fawcitt, 'Radiology of the Manchester Mummies', in R. David (ed.), Manchester Museum Mummy Project: Multidisciplinary Research on Ancient Egyptian Mummified Remains (Manchester, I979), 38.

S. Ikram and C. Rossi, 'Surveying the North Kharga Oasis', KMT I3.4 (2002), 72-9; S. Ikram, 'The North Kharga Oasis Survey: A Brief Overview', in J.-C. Goyon and C. Cardin (eds), Proceedings of the Ninth International Congress of Egyptologists (Leuven, 2007), 953-9; S. Ikram, 'Egypt's Frontier Oasis: A Visual Journey', Archaeology 6r .6 (2008), 36-4I; S. Ikram, 'The North Kharga Oasis Survey', Bulletin of the American Research Center in Egypt 193 (2008), 28-3 I.

$2 \quad$ S. Ikram and C. Rossi, 'North Kharga Oasis Survey 200 -2002 Preliminary Report: Ain Gib and Qasr el-Sumayra', MDAIK 60 (2004), 69-92; C. Rossi and S. Ikram, 'North Kharga Oasis Survey 2003 Preliminary Report: Umm El-Dabadib', MDAIK 62 (2006), 279-306; S. Ikram and C. Rossi, 'North Kharga Oasis Survey 2004 Preliminary Report: Ain El-Tarakwa, Ain El-Dabashiya and the Darb Ain Amur', MDAIK 63 (2007), I6784; C. Rossi and S. Ikram, 'North Kharga Oasis Survey 2007 Preliminary Report: Ain Lebekha and Ain Amur', MDAIK 66 (2010): 235-42.

3 C. Rossi and S. Ikram, 'Petroglyphs and Inscriptions along the Darb Ayn Amur, Kharga Oasis', ZZ̈ S I 29 (2002), I42-5I; S. Ikram, 'Brief Report of the North Kharga Oasis Survey's 2005 Season', Bulletin of the American Research Center in Egypt I 87 (2005), 8- I ; S. Ikram, 'Paths, Petroglyphs, and Piety: The North Kharga Oasis Survey 2006 Season', Bulletin of the American Research Center in Egypt 190 (2006), I8-23; S. Ikram, 'Drawing the World: Petroglyphs from Kharga Oasis', ArchéoNil i9 (2009): 67-82; S. Ikram, 'A Desert Zoo: An Exploration of Meaning and Reality of Animals in the Rock Art of Kharga Oasis', in H. Riemer, F. Förster, M. Herb, and N. Pöllath (eds), Desert Animals in the Eastern Sahara: Status, Economic Significance, and Cultural Reflection in Antiquity. Proceedings of an Interdisciplinary ACACIA Workshop held at the University of Cologne, December I4-I5, 2007 (Colloquium Africanum 4; Köln, 2009), 263-9I; C. Rossi and S. Ikram, 'Evidence of Desert Routes across Northern Kharga (Egypt's Western Desert)', in H. Riemer and F. Förster (eds), Desert Road Archaeology (Köln, 20I3). 


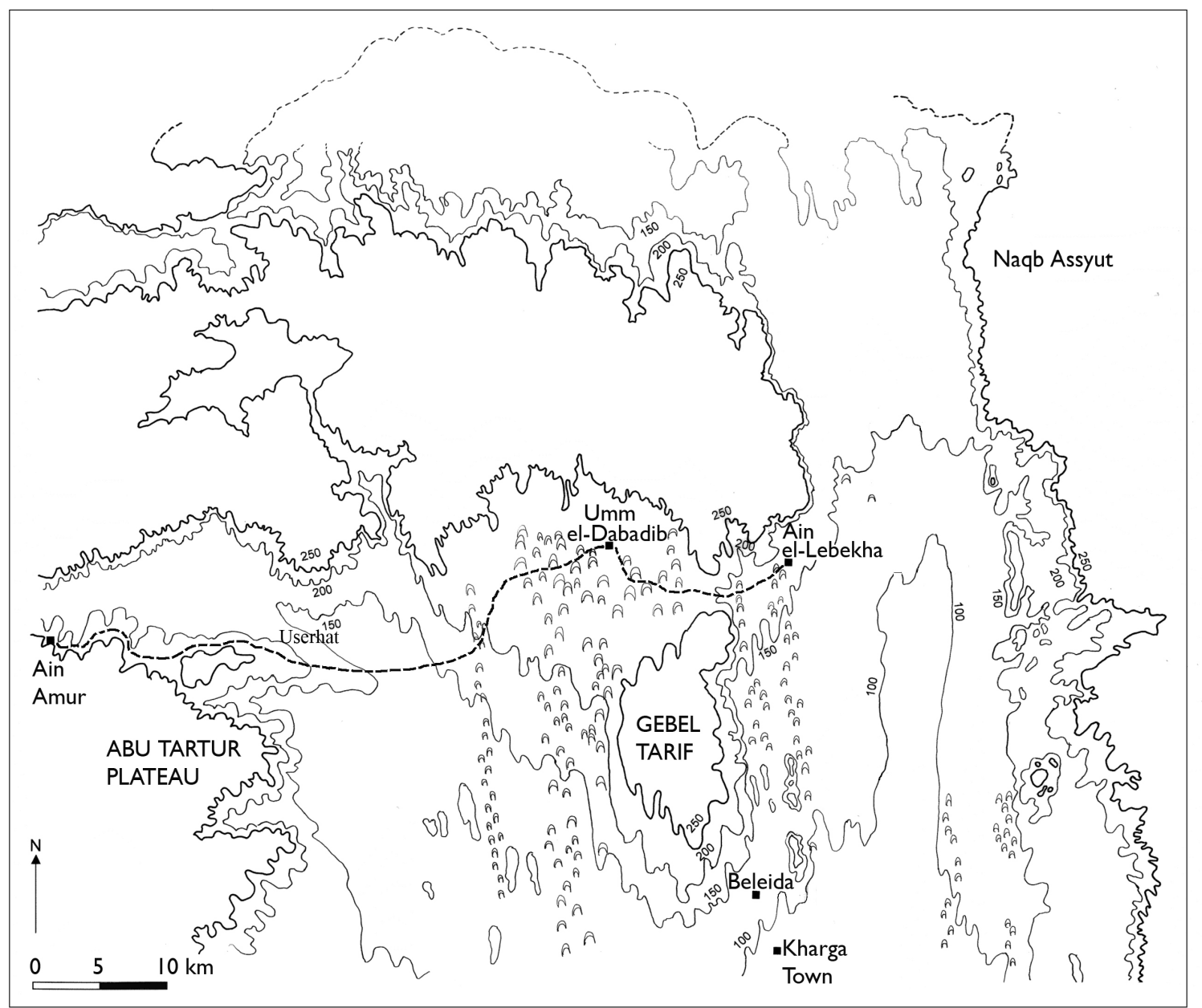

FIG. I. Schematic map of Kharga Oasis showing the Darb Ain Amur and Userhat's inscription (drawing by N. Warner).

several sites, dating virtually to all eras of Egyptian history, including prehistoric, Early Dynastic, Dynastic, Demotic, Ptolemaic, Roman, Coptic, Bedouin and Arab petroglyphs, plus large amounts of ceramics and small objects found in the vicinity of natural shelters that have been used by travellers of all periods.

Among the mass of material that has been so far located and studied, two inscriptions appear to be of particular importance, both for their intrinsic value and for the implications they entail. One is the serekh of a previously unknown king, dating to Dynasty Zero or the First Dynasty: its presence, halfway between the green centres of Kharga and Dakhla, suggests that the range of action of the earliest kings extended as far as these two oases, and probably beyond. ${ }^{4}$

The second inscription, the 'Userhat Inscription', thus designated after the name of its author and the focus of this article, was found along the section of the ancient route that skirts the Abu Tartur plateau, on a small sandstone knoll. It is incised on the southern side, protected from the gusting north wind. There are some shallow overhangs and protected spaces on this side of the rock that still provide shelter from the elements. Someone with a confident hand cut the inscription into a relatively flat, slightly sloping part of the knoll. Although the majority of the ceramics scattered around the rock were of Roman date (third to fifth century AD), together with Ottoman remains in the form of a pipe bowl, a few sherds come from New Kingdom amphorae of a type regularly found along the Darb Ain Amur, ${ }^{5}$

4 S. Ikram and C. Rossi, 'An Early Dynastic Serekh from the Kharga Oasis', $\mathscr{F} E A$ 90 (2004), 2 I I-I 5. An identification confirmed by NKOS ceramicists L. Warden and P. J. Rose. 
tying in nicely with the inscription. Above the inscription, at the upper left proper corner, are a few incised signs that, based on their position and patina, are not an original part of it.

The inscription consists of two slightly unequal columns of hieroglyphs read from right to left, with the right column being slightly longer (figs 2 and 3 ). The right column reads: imn wsr $h 3 t^{\circ}$, while the left column reads: $z \check{s} h z b k 3(. w){ }^{6} \mathrm{~A}$ few faint, illegible signs of a different size from the inscriptions barely show above the upper right corner of the Userhat inscription, and might be the remains of an earlier text. The text can be read in three ways: first, the cattle-reckoning scribe of Amun-userhat; second, Amun-userhat, the cattlereckoning scribe; third, if read in retrograde: the cattle-reckoning scribe of Amun, Userhat. ${ }^{7}$

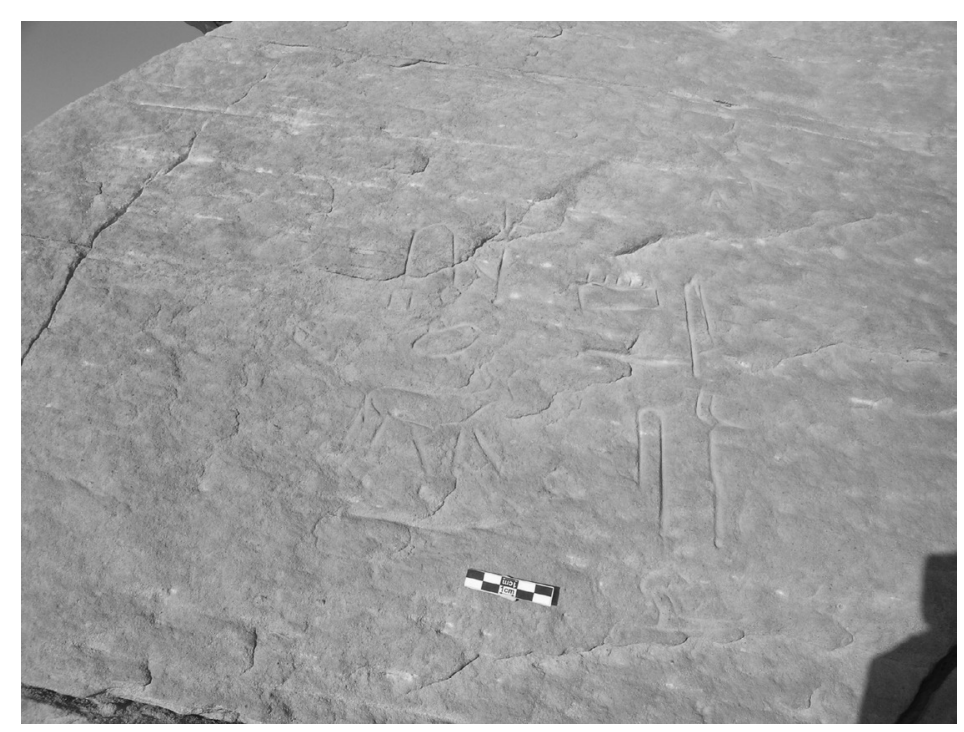

FIG. 2. Photograph of the Userhat inscription, in situ (photograph by S. Ikram).

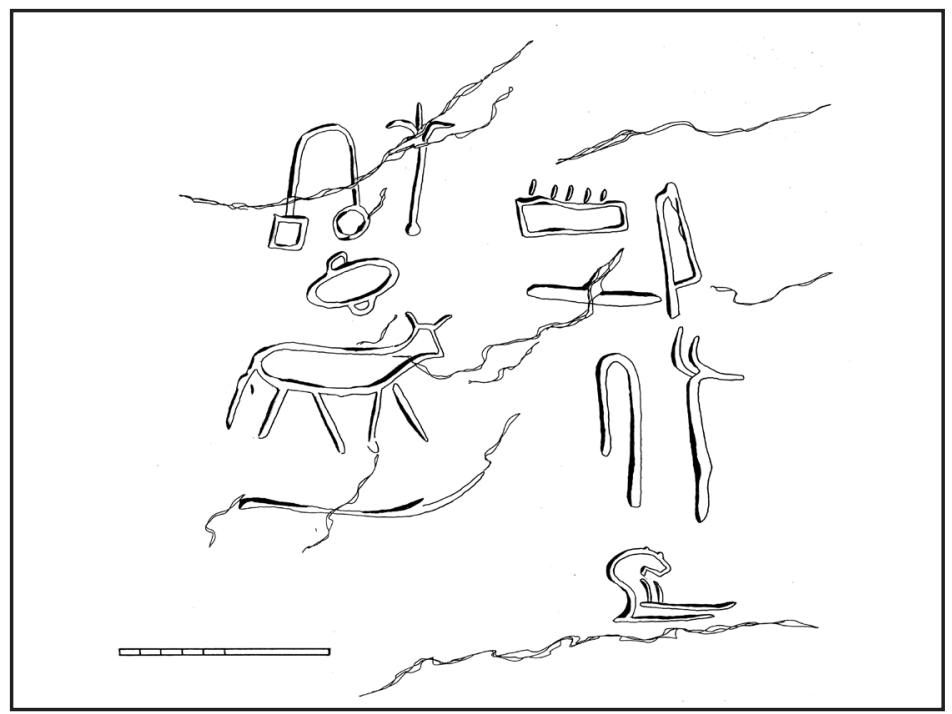

FIG. 3. Drawing of the inscription (C. Rossi).

6 It is not easy, for the most part, to use palaeography to date rock inscriptions, as often the way of writing and the choice of signs are due to the exigencies of writing on rock.

7 The authors wish to thank Brett McClain of Chicago House for fruitful discussions on this inscription. 
In the first option - reading the columns according to their normal orientation - the divine name is read in honorific transposition, with Amun-userhat being the divine barge of Amun at Karnak, which could itself be deified. However, there is no evidence that it was provided with its own endowment of cattle, complete with accompanying scribes to keep track of them. ${ }^{8}$ Additionally, the author of the graffito would thus remain unattested by name, which, surely defeats the purpose of leaving such an inscription.

Although the second option, 'Amun-userhat, the cattle-reckoning scribe', is certainly possible, it is less attractive and feasible than the third option. For one thing, although the personal name Amun-userhat is known from the New Kingdom, ${ }^{9}$ it is far less common than Userhat. ${ }^{10}$ Also, there are no known instances (to these authors) of an Amun-userhat with a title of scribe associated to cattle. Furthermore, 'the cattle-reckoning scribe of Amun' is a standard reading for this title for the New Kingdom. ${ }^{\text {II }}$

Thus, the third reading of the text is the most convincing. Userhat is a relatively common New Kingdom name (particularly of the late Eighteenth and early Nineteenth Dynasties), as various finds from the Theban area attest. ${ }^{\mathrm{I} 2}$ Among the individuals who bear this name, two also bear similar titles: one lived under Amenhotep II and was buried in TT56 at Sheikh 'Abd el-Qurnah; ${ }^{13}$ the other lived in the late Eighteenth Dynasty and was buried in the small unfinished tomb TT ${ }_{5}$ o at Dra' Abu el-Naga.

Little is known about the Userhat for whom TTI50 was cut. The T-shaped tomb was never finished, only parts of the transverse hall (the south-east section) having been decorated with images of the deceased and his wife. He bore the titles of 'Overseer of the Cattle of Amun', as well as, possibly, 'Royal Scribe and Counter'. ${ }^{14}$

In the inscriptions that decorate the walls of his tomb, Userhat of $\mathrm{TT}_{5} 6$ bears, amongst others, the titles of 'Scribe', 'Royal Scribe' and 'Scribe and Counter of the Bread in Upper and Lower Egypt', as well as 'Superintendent of the Cattle of Amun'. ${ }^{15}$ In I903 Robert Mond found a funerary cone inscribed with the title 'Scribe of Upper and Lower Egypt, Royal Scribe, Counter of the Bread, Superintendent of the Cattle of Amun Userhat', ${ }^{16}$ in the tomb. Another funerary cone purchased by Schiaparelli fifteen years earlier and said to come either from Dra' Abu el-Naga or Assasif, bore the same inscription as the one found by Mond and also presumably originated from this tomb. ${ }^{17}$

Although the Kharga Userhat cannot be indisputably identified with either of the Userhats buried in the Theban area, his name and titles point to the same basic historic period of the owners of $\mathrm{TT}_{5} 6$ and $\mathrm{TT}_{15} \mathrm{O}$, and more probably, given the string of titles and the tomb decoration involving cattle, to the owner of $\mathrm{TT}_{5} 6$. The Kharga Userhat, therefore, could well have been the owner of $\mathrm{TT}_{5} 6$, who travelled westwards across the desert to Kharga,

\footnotetext{
8 The authors are indebted to Brett McClain for pointing out the divine barque interpretation.

$9 \quad$ H. Ranke, Die Ägyptischen Personennamen I (Glückstadt, I 935), 27.

ro Ranke, Personennamen, 85 .

iI A. Erman and H. Grapow, $W b$. III, i67.

I2 Ranke, Personennamen, 85; B. Porter and R. Moss, Topographical Bibliography of the Ancient Egyptian Hieroglyphic Texts, Reliefs and Paintings, The Theban Necropolis, I: Private Tombs (Oxford, I 960), I8, 48, 87, 97, 323, 329, 381, 4I 7, 452; B. Porter and R. Moss, The Theban Necropolis I.2: Royal Tombs and Smaller Cemeteries (Oxford, I 964), 562, 700-I, 782, 789, 792, 80I-2, 805, 8I 6. See also R. Mond, 'Report of Work in the Necropolis of Thebes', $A S A E 6$ ( 1906), 69-70; H. Gauthier, 'Rapport sur une campagne de fouilles à Drah Abou'l Neggah en I 906', BIFAO 6 (I 908), I3 I-2 and E. Naville, The XIth Dynasty Temple at Deir el-Bahari I, (London, I907), 24, 5 I. For Middle Kingdom Userhats, see Porter and Moss, Topographical Bibliography, Theban Necropolis, I,

I3 Porter and Moss, Topographical Bibliography I. I, I I I-I3, 26 I

I4 Gauthier, BIFAO 6, I3 I.

15 C. Beinlich-Seeber and A. G. Shedid, Das Grab des Userhat (TT56) (Archäologische Veröffentlichungen 5०; Mainz, г 987), 103-6.

i6 Mond, $A S A E$ 6, 9I and 95 .

17 A. Pellegrini, 'I coni funerari del Museo Archeologico di Firenze', Bessarione 7, Serie 2, vol. 3, fascicolo 67 ( 1902), 8. The cone is on display in the Museo Egizio of Florence. We would like to thank Maria Cristina Guidotti for facilitating access to the object.
} 657. 
Dakhla, and even perhaps Farafra. The name of the latter was generally written with a cow sign, perhaps indicating an abundance of these animals here at one time. ${ }^{18}$ This picture agrees with the little information that we possess on the New Kingdom exploitation of the Western Desert, in particular during the Eighteenth Dynasty. In this period, wh3t, the general name of the Western Desert oases, occurs in the tombs of a certain number of Theban officials bearing titles relating to the administration of the Amun temple. As Lisa Giddy pointed out, it appears that some of the provisions for the Amun estate came from the oases, and it is even possible that a domain of the god was actually located somewhere in the region of wh $3 t .{ }^{19}$ Certainly, ceramic finds between Kharga and Dakhla point to a regularly used track during this period. ${ }^{20}$ The location of the inscription of the Kharga Userhat, on a rock along the shorter route between Kharga and Dakhla, now known as the Darb Ain Amur, is logical for an official who travelled to the oases to check (or gather) the provisions that the region owed to the Amun estate of Thebes (fig. I). It is therefore possible to conclude that part of the temple estate lay beyond Kharga, possibly in Dakhla (Ain Amur was probably too small to represent the final destination of Userhat's journey). Indeed, this is in keeping with the New Kingdom activity documented at Dakhla in recent years. ${ }^{2 \mathrm{I}}$

The choice of route suggests that Userhat was part of a light-laden caravan that preferred to go from Kharga-probably near the area of Hibis-west across the desert, possibly stopping at the spring at Umm el-Dabadib, before continuing on to the quick but steep ascent to the Gebel Abu Tartur plateau, rather than taking the longer and waterless journey on flat ground along the Darb el-Ghubbari, circumnavigating Gebel Abu Tartur along its southern border. Therefore, either Userhat was heading to Dakhla via Ain Amur and planning to return with a heavy load along the other route, or he was travelling light, accompanied by only a few people and donkeys, going only to inspect the temple estate. ${ }^{22}$ We hope that in either case, this graffito will add another detail to the picture of New Kingdom exploitation of the oases ${ }^{23}$ and the region of the Western Desert. Perhaps future work in Dakhla will shed light on Userhat's final destination and activities, thereby adding to his tale as well as to the history of the oases.

Corinna Rossi and Salima Ikram

\section{From steering oar to embalmer's tool: Re-identification of an artefact}

The re-identification of a single steering oar from the Medelhavsmuseet in Stockholm, and a pair of oars in the British Museum.

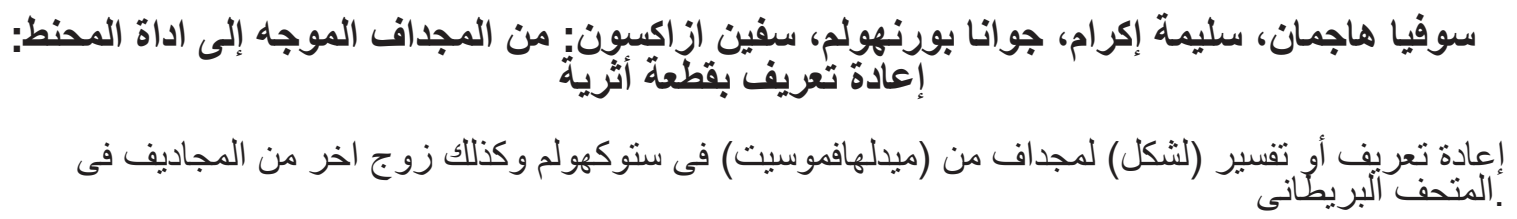

I8 L. L. Giddy, Egyptian Oases (Warminster, I987), I 52-3, table VI; 47-8; E. M. Sakr, 'The Economic and Administrative Situations of Egyptian Oases from the Ancient Times till the First Intermediate Period', in N.Bonacasa et al. (eds), The Culture of the Oasis from the Antiquity to the Modern Age (Cairo, I 998), 33-42. It should be noted that thus far no faunal evidence to support a dense population of cattle has been found here.

I9 Giddy, Egyptian Oases, 68-75, esp. 7I

20 The ceramics have been identified by L. Warden and P. J. Rose; a publication is in preparation.

${ }^{21}$ C. A. Hope, 'Oases Amphorae of the New Kingdom', in R. Friedman (ed.), Egypt and Nubia: Gifts of the Desert (London, 2002), 95-13 I; Hope pers. comm.

${ }^{22}$ Userhat could have taken a number of routes between the Nile Valley and Kharga, in part depending on whether he left from Thebes or elsewhere. See: J. C. Darnell et al., The Theban Desert Road Survey I: The Rock Inscriptions of Gebel Tjauti in the Theban Western Desert, Part I, and the Rock Inscriptions of the Wadi el Hôl, Part I (Chicago, 2002); D. Darnell, 'Gravel of the Desert and Broken Pots in the Road', in Friedman (ed.), Egypt and Nubia, I 56-77; J. C. Darnell, 'Opening the Narrow Doors of the Desert: Discoveries of the Theban Desert Road Survey', in Friedman (ed.), Egypt and Nubia, 132-55.

${ }^{23}$ The textual sources provide abundant evidence that Kharga was inhabited, that its land was successfully exploited, and that it played an active role in the life of the Nile Valle. See: Giddy, Egyptian Oases, 89 and 97-8. 